\title{
ASSESSMENT MODEL APPLICATION OF WATER SUPPLY SYSTEM MANAGEMENT IN CRISIS SITUATIONS
}

\section{PIETRUCHA-URBANIK K.}

\author{
Rzeszow University of Technology \\ Faculty of Civil and Environmental Engineering
}

35-959 Rzeszow, Al. Powstańców Warszawy 6, Poland

Received: 23/04/2014

Accepted: 30/07/2014

Available online: $21 / 11 / 2014$

ABSTRACT

Due to the fact that water systems belong to critical infrastructure, diverse methods of its management assessment during crisis situations are applied. In these methods both technical aspects and human factors, that have an impact on safety of water supply to the recipient, are considered. Also assessment tools for water supply were applied for failure assessment in the water supply system (WSS) management. The safety functioning of WSS is associated with analysis of relations between threats, reducing the frequency of their appearing, and, if threats appear, with the identification of their causes and reducing their negative consequences. Undesirable events are the result of phenomena independent from the human will, as well as those related to human activity, that in a significant way influence the WSS functioning. Crisis situations that are affected by such undesirable events having nonrandom (rare events do not have the statistical stability), but also not-determined character, demand specific and interdisciplinary research methods.

Keywords: water supply system, crisis situation, critical infrastructure, management.

\section{Introduction}

At present a considerable increase of interest in ensuring water supply during special conditions, like for example in crisis situation, is observed, which meets with very good reception of water consumers. Until recently the safety of critical infrastructure, to which water infrastructure belongs, was being associated only with its technical condition. Currently, the safety is being related to its broader meaning. It concerns the system man-technology-environment (Rak, 2007; 2009). The general typology of threats related with WSS safety is as follows (Rak and Pietrucha, 2008): associated with the unreliability of technology, natural disasters (floods, droughts, hurricanes, earthquakes), associated with man's activity: bad intentions (e.g. terrorism, sabotage), the ignorance of employees, the incompetence of the operator. There is a possibility of mutual interactions of the individual types of threats. Such understanding of safety increased the number of analysed threats, which, in turn, caused the conscious increase of the water infrastructure resistance to undesirable events and, consequently, the increase of the safety management (Babiarz 2006; Vintr, 2007).

Water supply companies, in order to ensure the efficient and sustainable operation in the new market conditions, introduce a quality management system that complies with the requirements of international standard ISO 9001:2009 and ISO 24510(12):2007. As part of the developing science about safety management, specialised techniques are developed, which are based mainly on the quality methods. Water consumers' safety management can be implemented by the following quality systems: Quality Management, HACCP- Hazard Analysis Critical Control Points, RABC - Risk Analysis 
Biocontamination Control, GHP - Good Hygienic Practice, GMP - Good Manufacturing Practice, RASFF Rapid Alert System for Food and Feed.

For drinking water quality, the possible threats include pollution with dangerous substances that have an impact on threat to life, the health and the environment.

Hazard identification consists of distinguishing such situations, that have a negative impact on the water company functioning. Then the analysis of undesirable events should be performed, that will help in reducing effects of threats. Such assessment is designed to test the company vulnerability to the crisis situation occurrence. In the case of unsatisfactory assessment, appropriate action should be taken, which will improve the safety system, thus reducing vulnerability of the whole water company.

In many publications, the results of studies on water supply system management were presented (Studzinski and Pietrucha-Urbanik, 2012; Tchorzewska-Cieslak and Rak, 2010; Zimoch, 2009), with regard to a number of water supply systems (Carrion et al., 2009, Iwanejko and Bajer, 2009), and the results were obtained for virtually full range of wire diameters, distinguishing between age and pipe material (Le Gat and Eisenbeis, 2000), and operating conditions (Araujo et al., 2006; Juraszka and Braun, 2011; Kowalski, 2009; Pietrucha-Urbanik and Tchórzewska-Cieślak, 2014; Tabesh et al., 2009; TchorzewskaCieslak, 2011; Valis et al., 2010; 2012; Walkowiak and Mazurkiewicz, 2009; Xu et al., 2012). Effective assessment of WSS management is based, among others, on probabilistic data, experts opinions and linguistic descriptions, on the other hand is associated with many subjective factors, that reduce the effectiveness of probability theory in management assessment of WSS. Therefore a method which deals with such difficulties is needed (Sokołowski A. 2011; Wątroba, 2011).

As a result, it seems necessary to develop new methodology of assessment of WSS management, which would be as simple as possible and at the same time the obtained results would be satisfactorily reliable. Such approach will enable the widespread in water supply systems management. The aim of this paper is to present a novel approach to assessment management of WSS in crisis situation in aspect of safety and reliable supply of water to recipients.

\section{Method for failure assessment in water supply system management in crisis situation}

\subsection{Procedures connected with failure assessment in water supply system management}

Procedures connected with failure assessment in water supply system management are intended to identify and prioritize threats in order of importance. After such approach it is crucial to coordinate all activities associated with removing threats, what can be achieved by quickly reaction in reducing events which have negative influence on the WSS operating.

Procedure of failure assessment in water supply system management performs above tasks through establishing the purposes associated with the critical infrastructure safety and identifying the relations connected with the critical infrastructure. Obviously it is not possible to completely eliminate the water company vulnerability against the failures occurrence, but it can be reduced to satisfactory level, both in terms of technical and economic factors. To achieve this target, prioritization of the elements of critical infrastructure in order of importance, as well as critical infrastructure protection programs of the WSS should be implemented.

The measure of consequences in management of WSS functioning can be the financial losses associated with damaging of the individual WSS elements and the compensation paid when the lack of water lasts for a long time. The consequences should also include the damage to the water consumer health in case of drinking contaminated water. For water supply systems the consequences can be divided into the following groups: the economic consequences which influence the local/national economy, the consequences for the local governments that have influence on the ability to maintain order and provide minimum services by the state, the health consequences, affecting the health and comfort of the WSS recipients. If a failure appears, the consequences can have the following form: 
- lack or limited supplies of water for consumption, for the industry or the fire protection,

- a disastrous contamination with chemical or microbiological substances which influence the public health, from natural to intentional, biological, chemical or radiological water contamination,

- psychological impact on water recipients (e.g. fear against water use because of the belief that it is not clean, questions arising about the safety of the distribution system even after disinfecting),

- the negative economic and environmental influence (e.g. on the industry in which water is being used for production, necessity to provide the alternative sources of water by waterworks companies for domestic and economic needs, deficiency in water supply can influence the food production).

Consequences can have quantitative or quality character. The quantitative consequences include the health and the economic consequences and the quality consequences include the government and the psychological consequences. The assessment of the individual consequences should be made on the base of: services interferences size, the economic influence, number of illnesses or deaths occurring during/after crisis situation, the influence on the public confidence, constant problems resulting from the specific events, the treatment cost in case of drinking contaminated water, electricity or gas consumption for water boiling as to make it safe for drink, costs incurred for the system failure repair. While assessing the WSS operation in crisis situations one should remember about the fact that the failure of the given element can cause the expansion of failure to the other elements which is associated with an increase in incurred losses (Rak, 2007; Rak and Pietrucha, 2008).

\subsection{Development of analytical model for assessing the management of WSS functioning with implementation of validity predictors}

The determinants of the activity of each water company are: the functioning during crisis situation, conditions of water supply to recipients, and its effective service in the face of such an event. Evaluation of determinants will allow for a clear description of the water system functioning in crisis situation. Management of WSS functioning in crisis situation is inevitably associated with the reliability and safety of water supply to recipients. Thus, the higher level of reliability and safety of water supply to recipient, the better the management of WSS functioning is. Using this dependency based on the level of water supply reliability and safety the level of management of WSS functioning can be assessed.

Losses resulting from breaks and restrictions of water delivery to the recipients are an essential element that values operational scenario in the WSS. These losses are difficult to estimate, since there is no explicit relation between undelivered water and damages incurred to the recipient. The same lack of water supply can trigger different losses depending, for example, on the season, day of week, time of disturbance, etc. (Pietrucha-Urbanik, 2013).

In this case, it is worth considering the method of measuring reliability and safety level of water supply to the recipient. When choosing a tool for assessing the reliability level, one should remember that it must take into account all aspects of the assessment of the management functioning of water supply to customers. In this regard, the analysis of correlation and regression was proposed. Implementing such kind of analysis is used to determine to what extent the various statistical models explain the dependent variable (Wątroba, 2002). For performing the research by means of this method, at the beginning the parameters, which characterize the assessment of the functioning WSS in crisis situation should be specified.

In the paper crisis situations associated with lack of water supply to the recipients, which occurred in different water supply systems were analyzed. This type of event was assessed by individual customers, who experienced such disturbance.

On the basis of established indicators characterizing the water supply during crisis situations, consumers of water were presented with the questionnaire. A representative group of surveyed consisted of two hundred and twelve people. 
The recipients rated offered service using a 5-point scale. It should be remembered that due to the transparency of the survey, the number of indicators should be limited to the necessary minimum, as to choose the most important.

The most universal determinants that describe the services in the face of crisis situation in WSS are:

- general assessment of management of WSS functioning, in aspect of water supply to the recipient in a crisis situation,

- compensation for not meeting the quality standards of water supply in a crisis situation,

- $\quad$ ensuring by the water company a replacement water intake point and to inform customers of its location during crisis situations,

- way of notification of interruptions in water supply in time of crisis situations,

- the length of interruptions in water supply at the time of crisis situation.

After elaboration of the survey recipients were asked to complete it, that is to make an evaluation of the abovementioned aspects.

Subsequently, the analysis of survey was done, part of which is shown in Table 1.

Table 1. Part of the data file results associated with the water supply service in the face of crisis situation in WSS.

\begin{tabular}{clllll}
\hline Respondent & $\begin{array}{l}\text { General } \\
\text { assessment of } \\
\text { management of } \\
\text { WSS functioning }\end{array}$ & $\begin{array}{l}\text { Compensat } \\
\text { ion for not } \\
\text { meeting } \\
\text { the quality } \\
\text { standards } \\
\text { of water } \\
\text { supply }\end{array}$ & $\begin{array}{l}\text { Ensuring by } \\
\text { the water } \\
\text { company a } \\
\text { replacement } \\
\text { water intake } \\
\text { point }\end{array}$ & $\begin{array}{l}\text { Way of } \\
\text { notification of } \\
\text { interruptions } \\
\text { in water } \\
\text { supply }\end{array}$ & $\begin{array}{l}\text { The length of } \\
\text { interruptions in } \\
\text { water supply }\end{array}$ \\
\hline $\mathbf{1}$ & 3 & 5 & 2 & 1 & 3 \\
\hline $\mathbf{2}$ & 2 & 4 & 5 & 3 & 4 \\
\hline$\ldots$ & $\ldots$ & $\ldots$ & $\ldots$ & $\ldots$ & 2 \\
\hline $\mathbf{9 9}$ & 3 & 2 & 4 & 5 & 3 \\
\hline
\end{tabular}

The analysis started from checking the dependency between the General assessment of management of WSS functioning in aspect of water supply to the recipient in a crisis situation, with the other assessments. As to establish the connection degree between variables, the Pearson correlation was used. The results of the calculations concerning the relationship between General assessment of management of WSS functioning of water supply to the recipient with the other variables are presented in Table 2. From this analysis it is clear that the strongest association with the assessment of overall assessment of management of WSS functioning of water supply to the recipients has the length of interruptions in water supply, while the weakest is the assessment of Ensuring by the water company a replacement water intake point. In Table 2 values closer to 1 indicate that the higher the assessment is, the better the parameter evaluation of management of WSS functioning of water supply to the recipients in crisis situation. In this way the assessment of management of WSS functioning in terms of water supply to the recipient allows associating with the other determinants and identifying the weakest areas of activity, and thus introduces some measures to improve WSS functioning during a crisis situation. 
Table 2. Summary of Pearson correlation coefficients.

\begin{tabular}{|c|c|c|c|c|c|}
\hline \multirow[b]{2}{*}{ Determinant } & \multicolumn{5}{|c|}{$\begin{array}{l}\text { Marked correlations are significant with } p<0.05000 \\
N=212\end{array}$} \\
\hline & $\begin{array}{l}\text { General } \\
\text { assessment } \\
\text { of } \\
\text { management } \\
\text { of WSS } \\
\text { functioning }\end{array}$ & $\begin{array}{l}\text { Compensatio } \\
\mathrm{n} \text { for not } \\
\text { meeting the } \\
\text { quality } \\
\text { standards of } \\
\text { water supply }\end{array}$ & $\begin{array}{l}\text { Ensuring by } \\
\text { the water } \\
\text { company a } \\
\text { replacement } \\
\text { water intake } \\
\text { point }\end{array}$ & $\begin{array}{l}\text { Way of } \\
\text { notification of } \\
\text { interruptions in } \\
\text { water supply }\end{array}$ & $\begin{array}{l}\text { The length of } \\
\text { interruptions } \\
\text { in water } \\
\text { supply }\end{array}$ \\
\hline $\begin{array}{l}\text { General } \\
\text { assessment of } \\
\text { management of } \\
\text { WSS } \\
\text { functioning }\end{array}$ & 1.00 & 0.67 & 0.25 & 0,41 & 0.75 \\
\hline $\begin{array}{l}\text { Compensation } \\
\text { for not meet } \\
\text { the quality } \\
\text { standards of } \\
\text { water supply }\end{array}$ & 0.67 & 1.00 & 0.15 & 0.12 & 0.13 \\
\hline $\begin{array}{l}\text { Ensuring by the } \\
\text { water company } \\
\text { a replacement } \\
\text { water intake } \\
\text { point }\end{array}$ & 0.25 & 0.15 & 1.00 & -0.09 & 0.31 \\
\hline $\begin{array}{l}\text { Way of } \\
\text { notification of } \\
\text { interruptions in } \\
\text { water supply }\end{array}$ & 0.41 & 0.12 & -0.09 & 1.00 & 0.44 \\
\hline $\begin{array}{l}\text { The length of } \\
\text { interruptions in } \\
\text { water supply }\end{array}$ & 0.75 & 0.13 & 0.31 & 0.44 & 1.00 \\
\hline
\end{tabular}

Red color indicates a significant statistical correlation between variables.

In order to build a good qualitatively model, defining the cumulative effect by taking into account the assessment of all determinants on the general management of the WSS functioning of water supply to the recipient, the analysis was performed by using the Statistica software Multiple Regression. Calculations were made by implementing a stepwise progressive method, which consists of introducing or removing individual variables from the model assessment (Wątroba, 2011). Stepwise procedure thus allows construction of optimal solutions. In the context of dependent variable predicting, the significance analysis of the variable entry in the model was based on the statistics F-Snedecor. Table 3 shows the results of the presented analysis.

As a result of the analysis, the determinants: Compensation for not meeting the quality standards of water supply, Way of notification of interruptions in water supply and The length of interruptions in water supply entered the model, while variable describing ensuring a replacement water intake point will not be included in the regression equation. Impact of these determinants explains over $79 \%$ of the dependent variable variation. This can be inferred from the variable coefficient of determination $\mathrm{R}^{2}$ 
(Wątroba, 2002). In the case of forecasting the level of General assessment of management of WSS functioning, based on the estimated regression model, the average error analysis is approximately one.

Table 3. Summary of multiple regression results.

\begin{tabular}{|c|c|c|c|c|c|c|}
\hline \multirow{5}{*}{ Variable } & \multicolumn{6}{|c|}{ Summary of the dependent variable regression: } \\
\hline & \multicolumn{6}{|c|}{$\begin{array}{l}\text { General assessment of management of WSS functioning, in aspect of } \\
\text { water supply to the recipient, } N=212\end{array}$} \\
\hline & \multicolumn{6}{|c|}{$R=0,88965603 R^{2}=0.79148786$ Correct. $R^{2}=0.68723179$} \\
\hline & \multicolumn{6}{|c|}{$F(4,6)=33.592 p<0.0000$ Std. err. of est.: 1.0750} \\
\hline & Beta & $\begin{array}{l}\text { Std. err. } \\
\text { - Beta }\end{array}$ & B & $\begin{array}{l}\text { Std. err. } \\
\text { - from B }\end{array}$ & $t(95)$ & p-value \\
\hline Absolute term & - & - & 1.272354 & 0.387349 & 2.028742 & 0.033457 \\
\hline $\begin{array}{l}\text { Compensation for not } \\
\text { meeting the quality } \\
\text { standards of water } \\
\text { supply }\end{array}$ & 0.519729 & 0.052184 & 0.35426 & 0,037226 & 6.62453 & 0.000000 \\
\hline $\begin{array}{l}\text { Way of notification of } \\
\text { interruptions in water } \\
\text { supply }\end{array}$ & 0.239437 & 0.064937 & 0.12945 & 0.031568 & 2.40853 & 0.011987 \\
\hline $\begin{array}{l}\text { The length of } \\
\text { interruptions in water } \\
\text { supply }\end{array}$ & 0.119252 & 0.066139 & 0.08134 & 0.042928 & 1.489245 & 0.059192 \\
\hline
\end{tabular}

The obtained in this case model illustrates the dependence:

$\widehat{Y}=1.272+0.354 \cdot x_{1}+0.129 \cdot x_{2}+0.081 \cdot x_{3}$

where:

$\hat{Y}$ - predicted assessment of management of WSS functioning,

$\mathrm{x}_{1}$ - compensation for not meeting the quality standards of water supply in a crisis situation,

$\mathrm{x}_{2}-$ way of notification of interruptions in water supply during crisis situations,

$x_{3}-$ the length of interruptions in water supply during a crisis situation.

The impact of individual assessments on the overall model shape can be determined on the basis of these partial regression coefficients. It should be noted that the determinants assessment, will improve the management of WSS functioning in water supply to the recipient in a crisis situation.

While considering the improvement of functioning management of WSS in aspect of water supply in crisis situation, the following factors should be taken into account: nationwide and local interests and customs, data about past events and scenarios, economic conditions, different character of undesirable events, modification of undesirable events perception, establishment of financially justified safety margins, useful opinion, which can be obtained through surveys, the alternative decision strategies on various undesirable events, also profit and loss balance for individual operations preventing undesirable events.

\section{Conclusions and perspectives}

To ensure WSS operating and management safety in crisis situation it is required to use the newest theoretical solutions, which consist of the evaluation of the relation between the occurring threats and 
the safety and protective barriers. Ensuring safe use of the public water supply system and associated with it management in crisis situation requires considering the category of reliability and safety. A contemporary tendency ensuring the WSS safety operating assessment in crisis situation should constitute the main element of the managing system of the urban water networks, particularly in the strategic modernization plans. The presented method for the evaluation of WSS management in face of occurrence of undesirable events takes into account the recipients, which are exposed to such situation and therefore the distribution system should include protection and counteracting.

The use of the proposed method can significantly support management analysis of water supply system. The establishment of the assessment parameters is a very important issue that requires the use of experience from water practice. Moreover, it is based on the statistic data on the WSS operating.

In the perspective of further research presented proposals aim to obtain reliable assessment procedures of WSS and achieve the assessment model of its management in crisis situation. Also the developed methods allow for decision support in the assessment of the economic efficiency of the functioning of the water supply infrastructure.

Determination of parameters for assessing WSS management in crisis situation allows for comparison taking into account different scenarios. This will allow assessing the operational effectiveness of the system in emergencies, before taking preventive action.

Presented method and the possibility of its implementation allow to identify weak points of WSS management, which results in taking effective action in a crisis situation.

The obtained indicators allow to perform comparative analysis which shows the influence of various factors on the management of the system and characterizes fulfillment function in crisis situation.

\section{References}

Araujo L., Ramos H. and Coelho S. (2006), Pressure control for leakage minimisation in water distribution systems management, Water Resources Management, 20(1), 133-149.

Babiarz B. (2006), An introduction to the assessment of reliability of the heat supply systems, International Journal of Pressure Vessels and Piping, 83(4), 230-235.

Carrion A., Debon A., Cabrera E., Gamiz M.L. and Solano H. (2009), Failure risk analysis in Water Supply Networks, European Safety and Reliability Conf. (ESREL), 22-25 September 2008 Valencia, SPAIN Safety, Reliability and Risk Analysis: Theory, Methods and Applications, 1-4, 2447-2451.

Iwanejko R. and Bajer J. (2009), Determination of the optimum number of repair units for water distribution systems, Archives of Civil Engineering, 55(1), 87-101.

ISO 24510(12):2007 - Activities relating to drinking water and wastewater services - Guidelines for the assessment and for the improvement of the service to users. Guidelines for the management of drinking water utilities and for the assessment of drinking water services.

Juraszka B. and Braun S. (2011), Practical Aspects of Operating a Water Treatment Plant on the Example of WTP Wierzchowo, Rocznik Ochrona Srodowiska, 13(1), 973-988.

Kowalski D. (2009), Water Quality Management in a Water Distribution System, Ochrona Srodowiska, 31(3), 37-40.

Le Gat Y. and Eisenbeis P. (2000), Using maintenance records to forecast failures in water networks, Urban Water, 2(3), 173-181.

Pietrucha-Urbanik K. (2013), Multidimensional comparative analysis of water infrastructures differentiation; in: Environmental Engineering IV, Pawłowski A., Dudzińska M. R., Pawłowski L. (eds), Taylor \& Francis Group, London, 29-34.

Pietrucha-Urbanik K. and Tchórzewska-Cieślak B. (2014), Water Supply System operation regarding consumer safety using Kohonen neural network; in: Safety, Reliability and Risk Analysis: Beyond the Horizon Steenbergen et al. (Eds), Taylor \& Francis Group, London: 1115-1120.

Rak J. and Pietrucha K. (2008), Some factors of crisis management in water supply system, Environment Protection Engineering, 34(2), 57-65. 
Rak J. (2009), Safety of water supply system (in polish), PAN, Warsaw.

Rak J.R. (2007,) Some aspects of risk management in waterworks, Ochrona Srodowiska, 29(4), 61-64.

Rak J.R. (2009,) Selected problems of water supply safety, Environment Protection Engineering, 35(2), 23-28.

Rak J.R. and Pietrucha K. (2008,) Risk in drinking water quality control. Scientific and Technical Conf. on Water and Wastewater Basis for Environmental Protection (School of Quality Water 2008), May 28-30 2008 Kolobrzeg, Poland, Przemysl Chemiczny, 87(5), 554-556.

Sokołowski A. (2011), Statistics in medicine - advanced methods. Course Materials.

Studzinski A. and Pietrucha-Urbanik K. (2012), Risk Indicators of Water Network Operation, Chemical Engineering Transactions, 26, 189-194. DOI: 10.3303/CET1226032.

Tabesh M., Soltani J., Farmani R. and Savic D. (2009), Assessing pipe failure rate and mechanical reliability of water distribution networks using data-driven modeling, Journal of Hydroinformatics, 11(1), 1-17.

Tchorzewska-Cieslak B. (2011), Matrix method for estimating the risk of failure in the collective water supply system using fuzzy logic, Environment Protection Engineering, 37(3), 111-118.

Tchorzewska-Cieslak B. and Rak J. (2010), Method of identification of operational states of water supply system. Editor(s): Pawlowski L., Dudzinska MR., Pawlowski A. 3rd Congress of Environmental Engineering, September 13-16 2009 Lublin, Poland, Environmental Engineering III, 521-526, DOI: 10.1201/b10566-83.

Valis D., Koucky M. and Zak L. (2012), On approaches for non-direct determination of system deterioration, Eksploatacja i Niezawodnosc - Maintenance and Reliability, 14(1), 33-41.

Valis D., Vintr Z. and Koucky M. (2010), Contribution to highly reliable items' reliability assessment. Proc. of the European Safety and Reliability Conf. ESREL 2009, September 07-10, 2009 Prague, Czech Republic. Reliability, Risk and Safety: Theory and Applications. Taylor \& Francis, 1-3, 1321-1326.

Valis D., Vintr Z. and Malach J. (2012), Selected aspects of physical structures vulnerability - state-of-the-art. Eksploatacja i Niezawodnosc - Maintenance and Reliability, 14(3), 189-194.

Vintr Z. and Valis D. (2007), Modeling and analysis of the reliability of systems with one-shot items, Proc. $53^{\text {rd }}$ Annual Reliability and Maintainability Symposium (RAMS), 22-25 January 2007 Orlando, IEEE, 380-385.

Walkowiak T. and Mazurkiewicz J. (2009), Analysis of Critical Situations in Discrete Transport Systems, Proc. $4^{\text {th }}$ International Conference on Dependability of Computer Systems, June 30-July 02, 2009 Brunow, 364-371.

Wątroba J. (2011), Directly to match the straight, or linear regression analysis in practice, Stat Soft, Poland, 31-44.

Wątroba J. (2002), Introduction to the variance analysis, Stat Soft, Poland, 51-61.

Xu Y., Huang G.H., and Xu T.Y. (2012), Inexact Management Modeling for Urban Water Supply Systems, Journal of Environmental Informatics, 20(1), 34-43.

Zimoch I. (2009), Monitoring of the Quality of the Water in Water-Pipe Networks: Reliability Interpretation of the Results, Ochrona Srodowiska, 31(4), 51-56. 